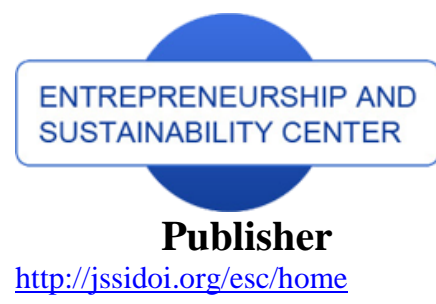

http://]ssidoi.org/esc/home
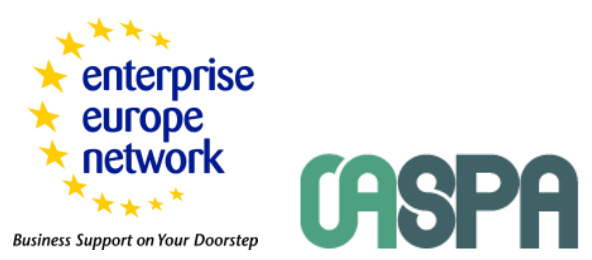

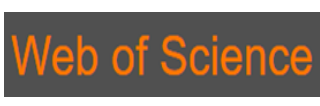

1 Clarivate

\title{
FINANCING OF YOUNG KNOWLEDGE-BASED COMPANIES AFTER THE FINANCIAL CRISIS: THE CASE OF KAZAKHSTAN
}

\author{
Gulzhan Isatayeva', Velena Seitova², Gulzhamal Koptayeva ${ }^{3}$, Altynai Turlybekova ${ }^{4}$, Aigul Mutaliyeva ${ }^{5}$ \\ ${ }^{1}$ South Kazakhstan State Pedagogical University, Shymkent, Kazakhstan \\ ${ }^{2}$ Turan University, Almaty, Kazakhstan \\ ${ }^{3}$ Miras University, Shymkent, Kazakhstan \\ ${ }^{4}$ Academic Innovation University, Shymkent, Kazakhstan \\ ${ }^{5}$ International Humanitarian Techncal University, Shymkent, Kazakhstan \\ E-mails: ${ }^{1}$ isatayeva7@mail.ru
}

Received 15 June 2018; accepted 15 December 2018; published 30 March 2019

\begin{abstract}
Following the financial crisis of 2008, more attention is paid to access to finance for young knowledge-based firms. A study conducted before the crisis showed that it was more difficult for knowledge-based firms to gain access to finance. However, none of the studies considered the differential effect of the crisis on young knowledge-based firms. This document examines this gap using the data set of 1155 firms in Kazakhstan for various sectors of the economy. The analysis was carried out in the context of the years before the crisis of 2002-2005 and after the crisis, when the economy significantly stabilized for 2014-2017. We believe that young knowledge-based firms are more likely to be rejected for financing than other firms, and this has significantly worsened in the post-crisis period. However, regressions that control a variety of characteristic characteristics show that the deterioration in the general conditions for financing. The results show that there are two questions in the financial system. The first is a structural problem that restricts access to finance for young knowledgebased firms. Secondly, the cyclical problem was caused by the financial crisis and significantly affected the young knowledge-based firms of various sectors of the economy.
\end{abstract}

Keywords: knowledge-based economy; financial instruments; financing knowledge; Kazakhstan

Reference to this paper should be made as follows: Isatayeva, G.; Seitova, V.; Koptayeva, G.; Turlybekova, A.; Mutaliyeva, A. 2019. Financing of young knowledge-based companies after the financial crisis: the case of Kazakhstan, Entrepreneurship and Sustainability Issues 6(3): 1226-1234. http://doi.org/10.9770/jesi.2019.6.3(12)

JEL Classifications: O16, O21, O31

\section{Introduction}

The consequences of the financial crisis of 2008 focused on access to finance for young companies. The financial crisis of 2008 firstly manifested in the banking sector (Degl'Innocenti et al., 2018). The increase in the key rate complicated the situation not only for business and consumers, but also for the banking sector, increasing the risks of non-return and lowering credit activity (Cubillas et al., 2018). A complex financial situation, right up to the 


\section{ENTREPRENEURSHIP AND SUSTAINABILITY ISSUES}

ISSN 2345-0282 (online) http://jssidoi.org/jesi/

2019 Volume 6 Number 3 (March)

http://doi.org/10.9770/jesi.2019.6.3(13)

deprivation of licenses, arose among a significant number of banks inside the country, plus the freezing of accounts of the largest domestic banks abroad. In addition, the consequences of the financial crisis have led to mistrust and increased risks of investing into young knowledge-based firms.

However, experts confirm that young knowledge-based firms will stimulate economic recovery (Degryse et al., 2018). In the conditions for the formation of a knowledge-based economy and the development of absolutely new forms of production, it is necessary to develop young knowledge-based firms in Kazakhstan. Every year in Kazakhstan there is an increase in young knowledge-based firms, which is $8 \%$. The development of young knowledge-based firms is an important area of public policy (Bartz and Winkler, 2016). However, most young knowledge-based firms have funding problems (Protogerou et al., 2017). In particular, young knowledge-based firms - those that introduce new products, processes or business models - are likely to create new markets, achieve rapid growth and help the economy recover. External finance can be especially important for young knowledgebased firms, as they lack internal resources to successfully commercialize innovation (Wang et al., 2017). However, these are young knowledge-based firms that often get harder to obtain financing (Keasey et al., 2018, Karabag, 2018, Rosenbusch et al., 2017, Mackevičius et al., 2018; Wang et al., 2018). Knowledge-based firms tend to have more risky business models that are important for creating new markets, but they are also valuable for banks. They often rely more on intangible assets than on physical property, but intangibles are difficult to assess because they are context specific and therefore difficult to use as collateral for lending. The data on this issue are not final, but some authors believe that the most important firms for the economy often find it more difficult to obtain financing (Petruzzelli, 2018). It will be noted that it is very important for Kazakhstan to attract investment for young knowledge-based firms.

However, although there is sufficient evidence of a general problem of access to finance in the economy, there is little evidence of how the credit crisis and its consequences have affected access to finance for young knowledgebased firms in particular. This led Colombelli and Quatraro (2018) to state that the specific short-term and longterm effects of the financial crisis after 2007 are an open question on which further research is needed. Studies have shown that investment in high-tech production can be reduced during this period.

\section{Methodology}

This survey is based on data from the National Agency for Technological Development, a government record of knowledge-based enterprises. We use two waves of data: 2002/5, 2014/17. This provides data on the characteristics of firms, including innovations and applications for financing. We use a combination of simple quantitative analysis and econometric analysis to investigate the relationship between high-tech production and access to finance, controlling both the characteristics of the firm and the likelihood of application. We also use the political implications of our research.

Our results show that young knowledge-based firms - those that introduce completely new products or processes have a higher probability of applying for funding than other firms (higher demand), but they are more likely to impede access to finance (limited supply). Of our two-dimensional results, innovative firms that apply for funding are more likely to find it difficult to obtain. This absolute effect of credit rationing has significantly worsened since the crisis.

This document introduces a number of publications in the literature on access to finance for young knowledgebased firms. This is the first thing that empirically examines the question of how the access to finance for young knowledge-based firms has changed after the crisis. To date, most of the financial information has been focused exclusively on venture capital and other equity instruments (Zhang and Mayes, 2018). Instead, we focus on more standard, but more common forms of finance. We are also expanding the analysis beyond the intensive high-tech 


\section{ENTREPRENEURSHIP AND SUSTAINABILITY ISSUES}

ISSN 2345-0282 (online) http://jssidoi.org/jesi/

2019 Volume 6 Number 3 (March)

http://doi.org/10.9770/jesi.2019.6.3(13)

R\&D industries (Bertoni et al., 2015). Moreover, our measure of innovation is more inclusive than in other studies, which tend to focus on R \& D activities.

\section{Access to finance for young knowledge-based firms}

Nevertheless, it is not always clear that innovative firms can gain access to the financial resources they need. For some time, researchers have been concerned about potential structural problems in the financial system that make it difficult for young knowledge-based firms to access finance they need (Cozza, 2018). In addition, the credit crisis of 2008 will have a cyclical effect. Credit limits will exacerbate the availability of finance for all firms and may also exacerbate problems for certain firms, in particular such as young firms.

There are three main reasons why there may be a structural problem of access to finance for young knowledgebased firms. First, returns to innovation may be uncertain and make innovation more risky for funding (Zhang, 2015, Hud and Hussinger, 2015, Dorner et al., 2017). Only a fraction of companies experience significant growth after investing in innovative activities because many products can not be successfully marketed or simply fail in the marketplace. There can be no assurance that investment in research and development (R \& D) will successfully lead to new products. The default rates are often high and make innovation a risky activity.

This problem of uncertainty can be particularly acute for young knowledge-based firms that are unable to invest in multiple projects and thus run the risk of putting all their eggs in one basket (Wang and Yang, 2012). Previous research has shown that the returns from innovation can be very different. A small number of innovative projects generate significant growth, but least of all low profits (Samagaio et al., 2018). Large companies are able to manage more diversified portfolios, and even if they have more outages, they are more likely to achieve at least a highly profitable innovation.

Second, there may be asymmetries that make it harder for banks to value innovative investments (Zhang et al., 2013). This is partly due to the uncertainty issues outlined above. But it could also be because innovative products are new by definition - they may require a special evaluation as provided by a venture capitalist. The skills needed to assess investments may differ from other types of firm's loans and investments and may be very sector specific. Because banks are less interested in the value of the company than venture capitalists or other external investors, they finance less innovation than a key criterion for banks. As the company has more information about the potential success of innovation than the financier, the innovation finance market may in some cases be similar to De Socio (2013) Lemon Market - a lack of information on which companies are worth funding increases the cost of finance and reduce the likelihood of successful applications.

Several studies have found evidence of a structural problem in providing finance to young knowledge-based firms. Research has focused more on the ability of companies to access the funding they need for innovation. Plank and Doblinger (2018) point out those financial resources are more of a factor hindering innovation young firms and high technology sectors. This is confirmed by studies using different data sets (Corredoira, 2018). Agénor and Canuto (2017) shows that small businesses applying are finding it harder to obtain loans than others, although their results are more compelling for R \& D-intensive young businesses than for those who introduce "novel" products and processes paper.

\subsection{Financing young knowledge-based firms in Kazakhstan}

It is clear from the table that the proportion of young companies from the high-tech industries in which investors are active does not differ between the two observation periods: f start-up companies from 2007 to 2012 and startups from 2014 to 2017 received funding. However, the number of companies they finance in the high-tech sector 
has fallen from around 231 (2002-2005) to 138 (2014-2017). Between the two observation periods, the number of start-ups has declined overall.

Within the high-tech industries, there are clear shifts in emphasis between the two periods considered. Thus, both the proportion and the absolute number of young companies with a commitment of funding in the high-end manufacturing segment (Software) increased significantly (the proportion from 0.87 to $5.80 \%$, the number from 2 to 8) while high-tech industrial sectors (Mining engineering and Aircraft engineering) can be said to be constant in the engagement of funding.

Table 1. Number and shares of companies financed by investors, founding cohorts 2002-2005 and 2014-2017

\begin{tabular}{|c|c|c|}
\hline Industry & $2002-2005$ & $2014-2017$ \\
\hline Aircraft engineering & $\begin{array}{c}1 \\
0,43 \%\end{array}$ & $\begin{array}{c}1 \\
0,72 \%\end{array}$ \\
\hline Mining engineering & $\begin{array}{c}2 \\
0,87 \%\end{array}$ & $\begin{array}{c}2 \\
1,45 \%\end{array}$ \\
\hline Software & $\begin{array}{c}2 \\
0,87 \%\end{array}$ & $\begin{array}{c}8 \\
5,80 \% \\
\end{array}$ \\
\hline Medically-led laboratory & $\begin{array}{c}5 \\
2,16 \% \\
\end{array}$ & $\begin{array}{c}8 \\
5,80 \% \\
\end{array}$ \\
\hline $\begin{array}{l}\text { High-tech } \\
\text { comp. }\end{array}$ & $\begin{array}{c}9 \\
3,90 \%\end{array}$ & $\begin{array}{c}13 \\
9,42 \%\end{array}$ \\
\hline Information technology & $\begin{array}{c}11 \\
4,76 \% \\
\end{array}$ & $\begin{array}{c}14 \\
10,14 \%\end{array}$ \\
\hline Automotive industry & $\begin{array}{c}5 \\
2,16 \% \\
\end{array}$ & $\begin{array}{c}10 \\
7,25 \% \\
\end{array}$ \\
\hline Biotechnology & $\begin{array}{c}11 \\
4,76 \%\end{array}$ & $\begin{array}{c}17 \\
12,32 \%\end{array}$ \\
\hline Electronic technology & $\begin{array}{c}40 \\
17,32 \%\end{array}$ & $\begin{array}{c}19 \\
13,77 \%\end{array}$ \\
\hline Construction & $\begin{array}{c}13 \\
5,63 \% \\
\end{array}$ & $\begin{array}{c}8 \\
5,80 \% \\
\end{array}$ \\
\hline Trade & $\begin{array}{c}31 \\
13,42 \% \\
\end{array}$ & $\begin{array}{c}14 \\
10,14 \% \\
\end{array}$ \\
\hline $\begin{array}{l}\text { Not high } \\
\text { tech comp. }\end{array}$ & $\begin{array}{c}101 \\
43,72 \% \\
\end{array}$ & $\begin{array}{c}24 \\
17,39 \%\end{array}$ \\
\hline Total & $\begin{array}{l}231 \\
100\end{array}$ & $\begin{array}{l}138 \\
100\end{array}$ \\
\hline
\end{tabular}

Financing also plays a not insignificant role in non-technology intensive sectors. Overall, the share of young enterprises in which funding are active is decreased from $43.72 \%$ till 17.39. It says that the proportion of funding to the knowledge-based enterprises increased only because of the government support.

\subsection{Financing young knowledge-based firms in Kazakhstan}

We use two measures, both in terms of morbidity and severity of limited restrictions (see Grilli and Murtinu, 2014). Specialists of funding sources, such as Venture Capital, are included, but they only apply to a small proportion of young knowledge-based firms (about 1 percent of those who apply for funding).

(1) Profiles, which had problems with financing from the first sources, tried.

(2) Firms that did not receive all the finances they needed from the first source they tried.

These measures reduce the level of regulation, not being able to access all the requested loans, and also point to the potential costs of searching, as initial applications are rejected and firms are looking for alternative sources. 


\subsection{Innovative firms and crisis}

The results above may be due to other characteristics of the firm, while innovative firms are more likely to seek growth or other characteristics that correlate with access to finance. In order to control this, we evaluate a series of regression model tests to see if firms have difficulty in obtaining finance. They take two forms: (1) regression probit, where the dependent variable is either a funding request, or one of the access measures to financing discussed above, or an option for application. In addition, we include aset independent variables that control other characteristics of the firm, which can be associated with both applications for financing and with the success of applications.

\subsection{Independent variables}

We also include control variables for a set of these brand characteristics: company size, age and sector and current changes in firm turnover. First, we control this with three age categories - whether they are firms aged 5-10 years or 11 years. The reference category is five years. In a recession, older firms became easier to obtain credit, although sometimes this was explained by their large size (Xiang et al., 2018).

Statistical data for the sample are shown in Table 2. Firms are usually relatively old, $39 \%$ older than 10 years, $40 \%$ - between the ages of 5 and 9 , and a minority - less than $5(19 \%)$.

Table 2. Variable list and summary statistics

\begin{tabular}{|l|l|l|l|l|l|}
\hline Variable name & Description & Mean & Std. Dev. & Min & Max \\
\hline Innovator & $\begin{array}{l}\text { 1 if firm has } \\
\text { introduced an } \\
\text { entirely new } \\
\text { product of process } \\
\text { in previous 12 } \\
\text { months; 0 if not. }\end{array}$ & 0.119 & 0.435 & 0 & 1 \\
\hline Post-recession & $\begin{array}{l}\text { Firm is sampled in } \\
\text { 2010 or 2012 (0 if } \\
\text { 2007/8) }\end{array}$ & 0.214 & 0.594 & 0 & 1 \\
\hline Age $>10$ & $\begin{array}{l}\text { Firms is aged } \\
\text { more than 10 years }\end{array}$ & 0.394 & 0.527 & 0 & 1 \\
\hline Age 5-10 & $\begin{array}{l}\text { Firm is aged 5-9 } \\
\text { years }\end{array}$ & 0.401 & 0.498 & 0 & 1 \\
\hline Age < 5 & $\begin{array}{l}\text { Firm is younger } \\
\text { than 5 years }\end{array}$ & 0.194 & 0.402 & 0 & 1 \\
\hline A total of 1155 observations. Summary statistics are unweighted. & & \\
\hline
\end{tabular}

\section{Results}

Table 3 presents our main outcomes which are probit regressions where the dependent variable is whether firms submitted funding requests (columns 1 and 2), and independent variables are the set of controls described above. Models 1 and 2 take into account the probability of that firms application for funding. The comparison with firms in the reference category reveals that firms based on knowledge are more inclined to apply for financing than other firms. Although the post- recession ratio has a positive meaning, it is not considerable at standard degrees. In column 2, the sample is divided into two groups of innovative firms: ones before and ones after the recession. Although the meaning of ratio for both variables is positive, in both cases it is not essential. But any effect has a larger power for innovators in post-recession period. 
Table 3. Probit regression results: Problems accessing finance

\begin{tabular}{|l|l|l|}
\hline & $(1)$ & $(2)$ \\
\hline Innovator & $0.127^{* *}$ & \\
& 0.0064 & \\
\hline $2002 / 5$ & 0.0317 & \\
& $(0.0548)$ & \\
\hline Non-innovator (2014/17) & & -0.00182 \\
& & $(0.0611)$ \\
\hline Innovator (2002/5) & & 0.114 \\
& & $(0.0740)$ \\
\hline Innovator (2014/7) & & 0.131 \\
& & $(0.112)$ \\
\hline Age 10+ & $-1.094^{* * * *}$ & $-0.653 * * *$ \\
& $(0.108)$ & $(0.141)$ \\
\hline Age 5-9 & $-0.194 * * *$ & 0.0187 \\
& $(0.0507)$ & $(0.0780)$ \\
\hline Obs & 1155 & 1155 \\
\hline Pseudo R2 & 0.0397 & 0.0397 \\
\hline
\end{tabular}

According to achieved results, knowledge-based companies have more difficulties in receiving finance in consideration with other firms, even controlling for relevant factors such as scale and sphere. The ratio on the 'knowledge-based' variable is considerable in opposition to each of the first three variables for trouble in accessing funding.

We likewise reveal that they tend to encounter absolute credit rationing from all sources, though the coefficient is only essential at the 10 per cent significance level. Our outcomes obtained show that the incapability of financing knowledge-based firms turns into a structural problem of financial system. Additionally, our evidence demonstrates that firms in 2002/5 are more likely to get a refusal of credit than those in 2014/7. In every model the ratio for the '2014/7' dummy is considerable. Loan conditions have deteriorated in the period for all firms, despite whether they are knowledge-based or not, representing the periodic effect of the crisis. The conspicuous exception to this common model is for absolute rationing from all sources. Before the financial crisis, knowledgebased firms were not especially likely to be incapable of finding finance from any source-since the crisis, they are much more likely to encounter absolute credit rationing. The control variables give further understanding of types of firms who have problem accessing finance. Each of these outcomes is unsuspected, and so suggests that choice maybe an issue and that these firms may be more likely to apply for finance. At the end, we find proof of the fact that age matters and that there is more difficult for younger firms to access finance.

\section{Conclusions}

Because of the large financial crisis, access to financing is getting to be thought an increasingly considerable barrier to business growth. It particularly turns into a problem in case it hinders innovative feeds from obtaining access to the funding they need to yield knowledge-based products and processes to the market, grow and create jobs in a definite region.

In this document, a large-scale survey of Kazakhstan knowledge-based firms before and after the crisis to explore the differential risk of a "credit crunch" on innovative firms (Mutanov etc., 2015).

The outcomes reflect the fact that young knowledge-based firms have more difficulties in getting access to financial resources in comparison with other firms. However, the worsening of loans accessibility conditions and, 


\section{ENTREPRENEURSHIP AND SUSTAINABILITY ISSUES}

ISSN 2345-0282 (online) http://jssidoi.org/jesi/

2019 Volume 6 Number 3 (March)

http://doi.org/10.9770/jesi.2019.6.3(13)

especially the amounts accessible for the past two years is systemic for all firms, and not for knowledge-based firms.

Moreover, in some respects the recession decreased the gap between the two groups of firms, possibly signifying surplus credit foremost before the crisis. But, these common conclusions are not verified when we distinctly regard the absolute credit rating from any source (ie, firms that are not able to obtain any finances at all). Knowledge-based firms started in a complete disadvantage in comparison with others.

Even so, whereas financing conditions have worsened in a crisis for both types of firms, the state of knowledgebased firms got worse for this reason and as a result knowledge-based firms are likely to encounter absolute credit rationing. Our outcomes have some effects for the theory in this area.

Indeed, some of the results may be connected to the transformed composition of firms, as some firms are closed in the crisis period. They are likewise consecutive with the theory of demand for goods with worsened balance sheets, which decreases the potential for firms for making investments using internal capital and, thus, provides their funding from the outside.

These theories also accord with our conclusion that, in spite of the deterioration in financing quality, the relative gap between innovative and non-innovative firms is covered. Taking into account the confined availability, banks may have looked for closer acknowledgment, which could enlarge investment in growth. It is difficult for them to reconcile with our conclusion that the absolute decline in rationing has worsened for innovative firms in both absolute and relative terms. The interpretation can be more usual, banks are ready to give a definite sum of incremental working capital to maintain firms, but are not able to provide large amounts of investment to bring new innovations to the market. According to our outcomes problems remain for young knowledge-based firms, and that it is not only due to the risk profiles. Actually, using standard credit scores, there are very few considerable distinctions in risk profiles between knowledge-based firms and other firms. This denotes that they give a new level to long-standing problems about the essence of bank funding for young knowledge-based firms in Kazakhstan (Sagiyeva et al., 2015).

Especially, there is a probability of discouragement when innovative firms lose willingness to look for financing. (Sagieva and Zhuparova, 2013). Our outcomes indicate that innovative firms, if at all possible, are more tended to apply for financing than before the recession. But, we are not able to say whether this is in virtue of the growth in demand for working capital, rather than long-term financing.

\section{References}

Agénor, P.R., Canuto, O. 2017. Access to finance, product innovation and middle-income traps. Research in Economics, 71(2): 337-355. https://doi.org/10.1016/j.rie.2017.03.004

Bartz, W., Winkler, A. 2016. Flexible or fragile? The growth performance of small and young businesses during the global financial crisis — Evidence from Germany. Journal of Business Venturing, 31(2): 196-215. https://doi.org/10.1016/j.jbusvent.2015.10.002

Bertoni, F., Croce, A., Guerini, M. 2015. Venture capital and the investment curve of young high-tech companies. Journal of Corporate Finance, 35: 159-176. https://doi.org/10.1016/j.jcorpfin.2015.08.012

Colombelli, A., Quatraro, F. 2018. New firm formation and regional knowledge production modes: Italian evidence. Research Policy, 47(1): 139-157. https://doi.org/10.1016/j.respol.2017.10.006

Corredoira, R.A., Goldfarb, B.D., Shi, Y. 2018. Federal funding and the rate and direction of inventive activity. Research Policy, In press, corrected proof, Available online 30 July 2018. https://doi.org/10.1016/j.respol.2018.06.009 


\section{ENTREPRENEURSHIP AND SUSTAINABILITY ISSUES}

ISSN 2345-0282 (online) http://jssidoi.org/jesi/

2019 Volume 6 Number 3 (March)

http://doi.org/10.9770/jesi.2019.6.3(13)

Cozza, C., Franco, C., Perani, G. 2018. R\&D endowments at home driving R\&D internationalisation: Evidence from the Italian business R\&D survey. Technological Forecasting and Social Change, 134: 277-289. https://doi.org/10.1016/j.techfore.2018.06.035

Cubillas, E., Suárez, N. 2018. Bank market power and lending during the global financial crisis. Journal of International Money and Finance, 89: 1-22. https://doi.org/10.1016/j.jimonfin.2018.08.003

Degl'Innocenti, M., Grant, K., Šević, A., Tzeremes, G. N. 2018. Financial stability, competitiveness and banks' innovation capacity: Evidence from the Global Financial Crisis. International Review of Financial Analysis, 59: 35-46. https://doi.org/10.1016/j.irfa.2018.07.009

Degryse, H., Matthews, K., Zhao, T. 2018. SMEs and access to bank credit: Evidence on the regional propagation of the financial crisis in the UK. Journal of Financial Stability, In press, Available online 30 August 2018. https://www.econstor.eu/bitstream/10419/146389/1/834458373.pdf

Dorner, M., Fryges, H., Schopen, K. 2017. Wages in high-tech start-ups - Do academic spin-offs pay a wage premium? Research Policy, 46 (1), 1-18. https://doi.org/10.1016/j.respol.2016.09.002

Grilli, L., Murtinu, S. 2014. Government, venture capital and the growth of European high-tech entrepreneurial firms. Research Policy, 43 (9): 1523-1543. https://doi.org/10.1016/j.respol.2014.04.002

Hud, M., Hussinger, K. 2015. The impact of R\&D subsidies during the crisis. Research Policy, 44(10): 1844-1855. https://doi.org/10.1016/j.respol.2015.06.003

Jian, W., You-Na, L., Walsh, J. 2018. Funding model and creativity in science: Competitive versus block funding and status contingency effects. Research Policy, 47(6): 1070-1083. https://doi.org/10.1016/j.respol.2018.03.014

Keasey, K., Martinez, B., Pindado, J. 2015. Young family firms: Financing decisions and the willingness to dilute control. Journal of Corporate Finance, 34: 47-63. https://doi.org/10.1016/j.jcorpfin.2015.07.014

Mackevičius, J., Šneidere, R., Tamulevičienè, D. 2018. The waves of enterprises bankruptcy and the factors that determine them: the case of Latvia and Lithuania. Entrepreneurship and Sustainability Issues, 6(1): 100-114. doi: 10.9770/jesi.2018.6.1(8)

Mutanov, G., Sagiyeva, R., Zhuparova, A. 2015. Measurement and Management of Knowledge Intensity Innovation Project. Innovation management and sustainable economic competitive advantage: from regional development to global growth, Vols I - VI, $3109-3112$

Plank, J., Doblinger, C., (2018). The firm-level innovation impact of public R\&D funding: Evidence from the German renewable energy sector. Energy Policy, 113: 430-438. https://doi.org/10.1016/j.enpol.2017.11.031

Petruzzelli, A.M., Ardito, L., Savino, T. 2018. Maturity of knowledge inputs and innovation value: The moderating effect of firm age and size. Journal of Business Research, 86: 190-201. https://doi.org/10.1016/j.jbusres.2018.02.009

Protogerou, A., Caloghirou, Y., Vonortas, S.N. 2017. Determinants of young firms' innovative performance: Empirical evidence from Europe. Research Policy, 46(7): 1312-1326. https://doi.org/10.1016/j.respol.2017.05.011

Rosenbusch, N., Brinckmann, J., Müller, V. 2013. Does acquiring venture capital pay off for the funded firms? A meta-analysis on the relationship between venture capital investment and funded firm financial performance. Journal of Business Venturing, 28 (3): $335-353$. https://doi.org/10.1016/j.jbusvent.2012.04.002

Sagiyeva, R., Alenova, K., Galimakair, A., Zhuparova, A. 2015. Management Innovation: Correcting Mistakes. Procedia Economics and Finance, 23: 856-860. https://doi.org/10.1016/S2212-5671(15)00339-1

Sagieva, R., Zhuparova, A. 2013. Innovation processes in Kazakhstan. Expert opinion. Sotsiologicheskie Issledovaniya, 9, $110-111$.

Samagaio, A., Crespo, N.F., Rodrigues, R. 2018. Management control systems in high-tech start-ups: An empirical investigation. Journal of Business Research, 89, 351-360. https://doi.org/10.1016/j.jbusres.2017.12.028

Socio, A. 2013. The interbank market after the financial turmoil: Squeezing liquidity in a "lemons market" or asking liquidity "on tap". Journal of Banking \& Finance, 37(5), 1340-1358. https://doi.org/10.1016/j.jbankfin.2012.09.023 


\section{ENTREPRENEURSHIP AND SUSTAINABILITY ISSUES}

ISSN 2345-0282 (online) http://jssidoi.org/jesi/

2019 Volume 6 Number 3 (March)

http://doi.org/10.9770/jesi.2019.6.3(13)

Solmaz, F.K. 2018. Factors impacting firm failure and technological development: A study of three emerging-economy firms. Journal of Business Research, In press, corrected proof, Available online 14 March 2018.

Wang, J., Yang, C. 2012. Flexibility planning for managing R\&D projects under risk. International Journal of Production Economics, 135 (2), 823-831. https://doi.org/110.1016/j.ijpe.2011.10.02

Xiang, D., Chen, J., Tripe, D., Zhang, N. 2018. Family firms, sustainable innovation and financing cost: Evidence from Chinese hi-tech small and medium-sized enterprises. Technological Forecasting and Social Change, In press, corrected proof, Available online 22 March 2018

Zhang, M., He, Y., Zhou, Z. 2013. Study on the Influence Factors of High-Tech Enterprise Credit Risk: Empirical Evidence from China's Listed Companies. Procedia Computer Science, 17, 901-910. https://doi.org/10.1016/j.procs.2013.05.115

Zhang, W. 2015. R\&D investment and distress risk. Journal of Empirical Finance, 32, 94-114. https://doi.org/10.1016/j.jempfin.2015.03.009

Zhang, Y., Mayes, D.G. 2018. The performance of governmental venture capital firms: A life cycle perspective and evidence from China. Pacific-Basin Finance Journal, 48, 162-185. https://doi.org/10.1016/j.pacfin.2018.02.002

Short biographical note about the contributors at the end of the article:

Gulzhan ISATAYEVA is $\mathrm{PhD}$ in Economics at South Kazakhstan State Pedagogical University, Shymkent, Kazakhstan. Research interests: innovation development; financing innovation processes; small firm internationalization; sustainability. ORCID ID: https://orcid.org/0000-0002-1388-5202

Velena SEITOVA is $\mathrm{PhD}$ student at Turan University, Almaty, Kazakhstan. Research interests: entrepreneurship and regional development; innovation and small firms; small firm internationalization; sustainability.

Gulzhamal KOPTAYEVA is PhD in Economics at Miras University, Shymkent, Kazakhstan. Research interests: entrepreneurship and regional development; innovation and small firms; small firm internationalization; sustainability.

Altynai TURLYBEKOVA is PhD in social sciences at Academic Innovation University, Shymkent, Kazakhstan. Research interests: entrepreneurship and regional development; human capital; small firm internationalization; sustainability.

Aigul MUTALIYEVA is $\mathrm{PhD}$ in Economics at International Humanitarian Techncal University, Shymkent, Kazakhstan. Research interests: entrepreneurship and regional development; human capital; small firm internationalization; sustainability.

Copyright (C) 2019 by author(s) and VsI Entrepreneurship and Sustainability Center

This work is licensed under the Creative Commons Attribution International License (CC BY).

http://creativecommons.org/licenses/by/4.0/

(c) (i) Open Access 